\title{
DIET AND TROPHIC GROUPS OF AN AQUATIC INSECT COMMUNITY IN A TROPICAL STREAM
}

\author{
MOTTA, R. L. and UIEDA, V. S. \\ Departamento de Zoologia, Instituto de Biociências, Universidade Estadual Paulista, \\ C.P. 510, CEP 18618-000, Botucatu, SP, Brazil \\ Correspondence to: Virginia S. Uieda, Departamento de Zoologia, Instituto de Biociências, Universidade Estadual \\ Paulista, C.P. 510, CEP 18618-000, Botucatu, SP, Brazil \\ Received August 27, 2003 - Accepted September 26, 2003 - Distributed November 30, 2004
}

(With 4 figures)

\begin{abstract}
The diet and trophic groups of an assemblage of aquatic insects were studied in a tropical stream. Genera of the orders Ephemeroptera, Odonata, Plecoptera, Lepidoptera, and Hemiptera showed feeding specialization. Others, such as Trichoptera, Coleoptera, and Diptera, showed great diet variation with genera of different trophic groups. Seasonal variation of insect diet, evident only for some genera of the orders Trichoptera, Lepidoptera, Coleoptera, and Diptera, was due to the differences observed in community composition and to generalist habits of these genera. However, the seasonal comparison of trophic groups showed no significant statistical differences. The great importance of organic matter, a non-limited resource, in the diet of Ribeirão do Atalho aquatic insects may be the explanation for the trophic stability in this community organization.
\end{abstract}

Key words: aquatic insects, diet, trophic groups, tropical stream.

\section{RESUMO}

\section{Dieta e grupos tróficos de uma comunidade de insetos aquáticos em um riacho tropical}

A dieta e o grupo trófico de uma assembléia de insetos aquáticos foi estudada em um riacho tropical. Os gêneros de algumas ordens de insetos, como Lepidoptera, Ephemeroptera, Plecoptera, Odonata e Hemiptera, apresentaram especialização alimentar. Por outro lado, as ordens Trichoptera, Coleoptera e Diptera mostraram grande variação na dieta, com gêneros de diferentes grupos tróficos. Alguns gêneros das ordens Trichoptera, Lepidoptera, Coleoptera e Diptera apresentaram variação sazonal na dieta relacionada a mudanças na composição da comunidade e à dieta generalista desses gêneros. Entretanto, a comparação sazonal de grupos tróficos mostrou diferenças não significativas estatisticamente. A grande importância da matéria orgânica, um recurso não limitado, na dieta dos insetos aquáticos no Ribeirão do Atalho pode ser a explicação para a estabilidade da organização trófica dessa comunidade.

Palavras-chave: insetos aquáticos, dieta, grupos tróficos, riacho tropical.

\section{INTRODUCTION}

Aquatic invertebrates predominate in the trophic structure of streams (Wallace et al., 1987) and their feeding habits can influence all aspects (life cycle, habitat choice, and behavior) of their life (Yule, 1996). Among invertebrates, aquatic insects are fundamental in understanding trophic structure in streams (Cummins, 1973). The trophic ecology of aquatic insects and their functional role in the environment are widely studied in the Northern Hemisphere. A complete review of such studies can be found in Allan (1995) and Merritt \& Cummins (1996). However, little is known about the feeding habits of aquatic insects in the Southern Hemisphere (Winterbourn et al., 1994; Yule, 1996) or, more 
specifically, in South America (Henderson \& Walker, 1986; Wais, 1990; Nessimian, 1997; Nessimian \& Sanseverino, 1998; Nessimian et al., 1999; Henriques-Oliveira et al., 2003).

The great importance of insects in the trophic structure of streams in contrast with the scanty data available in the literature about their feeding habits indicates the need of studies on this subject. Therefore, the purpose of this work was to investigate the diet and trophic groups of aquatic insects in a tropical stream.

\section{MATERIALS AND METHODS}

\section{Study area}

The study was carried out in the Ribeirão do Atalho (230' $\left.\mathrm{S}, 48^{\circ} 34^{\prime} \mathrm{W}\right)$, District of Itatinga, São Paulo State, Brazil. This stream is part of the Pardo river basin, one of the largest tributaries of the Paranapanema River. The study site is located at an elevation of $900 \mathrm{~m}$ and the stream is on average $0.4 \mathrm{~m}$ wide and $0.8 \mathrm{~m}$ deep. It presents clear water, a sandymuddy bottom, marginal herbaceous vegetation, and a great amount of aquatic macrophytes like Cyperaceae Rhychospora corimbosa (L.) Britt and Pontederiaceae Eichornia azurea Swart Kunt.

In the investigated region, the climate is tropically warm and wet, with only one dry month (July). There are two distinguishable seasons: a wet period between October and March and a dry period between April and September.

\section{Sampling and analyses}

Aquatic insects were collected during the wet (December 1993) and dry (August 1994) seasons, along a $75 \mathrm{~m}$ stretch of the stream. Specimens associated with aquatic macrophytes were sampled in two ways: 1) sieves ( $3 \mathrm{~mm}$ mesh) were agitated among the macrophytes and 2) six samples of macrophytes were collected manually to a $5 \mathrm{~cm}$ depth in a $900 \mathrm{~cm}^{2}$ square area. Benthic insects were sampled using a PVC pipe $\left(\varnothing 10 \mathrm{~cm}, 0.392 \times 10^{-3} \mathrm{~m}^{3}\right)$. All samples were preserved in $4 \%$ formalin. At the laboratory, the macrophytes were washed and scraped in preservative. The macrofauna was separated from the remaining material by sugar flotation (Havens et al., 1996).

The gut content of one to ten individuals of each taxon was analyzed and the area occupied by each food type was determined under a microscope using a Sedgewick-Rafter slide (biovolume method adapted from Esteves \& Galetti, 1995). Due to the feeding mechanism (piercer-suckers; Merritt \& Cummins, 1996), the gut contents of hemipterans could not be analyzed, but are considered as carnivores based on the Merritt \& Cummins (1996) and Bay (1974) descriptions.

\section{Trophic groups}

Gut contents were separated into six diet categories: particulate organic matter, filamentous algae, unicellular algae, terrestrial animals, aquatic animals, and vascular plants. The aquatic insects sampled in the Ribeirão do Atalho stream were assigned to trophic groups based on the dominant food (more than $60 \%$ of biovolume). Detritivores fed on both coarse and fine particulate organic matter, herbivores fed on living vascular plant tissues and/ or algae, carnivores preyed on animals, periphyton feeders consumed both algae and particulate organic matter associated with the microbiota, and omnivores utilized resources from two or more of the above trophic groups.

To evaluate if there was a significant seasonal variation of the trophic groups, the Chi-Square was used.

\section{RESULTS}

\section{Diet composition}

Seventy taxa were collected in the Ribeirão do Atalho, representing eight insect orders. Among these orders, Diptera presented the highest number of genera (33 taxa) and Ephemeroptera, the lowest (1 genus).

The major resource categories exploited by aquatic insects were organic matter, aquatic animals, and organic matter associated with algae (Fig. 1).

The trophic groups of detritivores $(41 \%)$, carnivores (39\%), and periphyton feeders (10\%) were predominant (Fig. 1). A diversified carnivorous group, composed mainly by genera of Odonata, Hemiptera, and Coleoptera fed on aquatic insects. The detritivorous group was as diversified as the carnivores, although composed mainly by Diptera genera.

\section{Trophic groups}

Genera of the Ephemeroptera, Odonata, Plecoptera, Lepidoptera, and Hemiptera orders showed feeding specialization. Mayflies were detritivores; stoneflies, periphyton feeders; 
lepidopterans, herbivores; and both dragonflies and hemipterans were carnivores (Fig. 2). The orders Trichoptera, Coleoptera, and Diptera showed great dietary variation, and their genera belonged to several different trophic groups. Only Trichoptera presented genera belonging to all trophic groups. Carnivores constituted the predominant Coleoptera group. Diptera, with the highest taxa richness, presented a predominance of detritivores $(44.7 \%)$, followed by periphyton feeders $(36.8 \%)$.

In the trophic group of carnivores, taxon richness was higher $(35.1 \%)$ than in the other four trophic groups (Fig. 2). Rotifers, microcrustaceans, annelids, and aquatic and terrestrial insects composed the diet of carnivorous aquatic insect orders (Fig. 3). Odonata fed mainly on aquatic insects and annelids; Trichoptera, predominantly on aquatic insects; and Coleoptera, mainly on aquatic and terrestrial insects.

\section{Seasonal variation in the diet}

Only the Trichoptera, Lepidoptera, Coleoptera, and Diptera orders showed seasonal dietary variation (Fig. 4), which was due to the differences observed in community composition as well as to seasonal diet variation of some genera.

This variation in the Trichoptera diet was determined by two caddisfly genera, Oxyethira and Leptonema, which themselves showed a seasonal diet variation, being detritivorous and omnivorous in the wet, and herbivorous and carnivorous in the dry period, respectively. Comparisons between the two seasons showed a reduction in the food items utilized by caddisflies in the dry season (Fig. 4).

The seasonal variation in the diet observed in the Lepidoptera order (Fig. 4) was due to the occurrence, restricted to the wet season, of Petrophila, which ingested algae and vascular plants.

The differences between the wet and dry periods for Coleoptera was determined by seasonal variation in the diet of Agabus (carnivorous in the wet and detritivorous in the dry period) and also by variation in the genera composition. A similar situation occurred for Diptera. Rheotanytarsus and Chelifera were periphyton feeders in the wet and detritivores in the dry period. Cryptochironomus and Nanocladius were both periphyton feeders in the wet, and omnivorous and carnivorous in the dry period, respectively. Ceratopogonidae was detritivorous in the wet and a periphyton feeder in the dry period.

Although seasonal variation was visible when comparing genera diet and occurrence, the relative importance of each trophic group per order was different in the seasonal analysis only for Trichoptera (Fig. 4). The lack of seasonal diet variation for the insect community studied was confirmed when the results of its trophic structure (number of taxa by trophic group) found during the wet and dry seasons showed no significant differences (Table $1, \chi^{2}=0.86$, $\mathrm{p}<0.05)$.

\section{DISCUSSION}

\section{Diet composition and trophic groups}

Most aquatic insects are opportunistic, ingesting a wide variety of food items available in their environments (Hynes, 1970; Cummins, 1973; Lamberti \& Moore, 1984; Allan, 1995; Mihuc \& Minshall, 1995). Based upon feeding mode and ingested detritus particle size (Cummins, 1973; Merritt \& Cummins, 1996), aquatic insects were grouped into six categories: collectors (gatherers and filterers), shredders, scrapers, and predators (engulfers and piercers). This classification of functional feeding groups developed for aquatic insects in the Northern Hemisphere is not easily applied in tropical streams (Winterbourn, 1995). According to King et al. (1988), transferring information on functional feeding groups between continents requires great caution.

It is important to recognize that most aquatic insects, such as chironomid larvae, are not limited to a single feeding mode, as has been pointed out by some authors (Nessimian \& Sanseverino, 1998; Nessimian et al., 1999; Henriques-Oliveira et al., 2003). Although functional group categories are based partially on the morphology of the species, there is considerable flexibility in the mode of feeding (Henriques-Oliveira et al., 2003). Due to this flexibility, gut content data analysis showed that the classification of the aquatic insects in trophic groups might be more appropriate for understanding resource utilization in insect communities than the classification of functional feeding groups. The trophic group of periphyton feeders used here corresponded to the functional feeding group of scrapers used by Merritt \& Cummins (1996). This author included the herbivorous and detritivorous trophic groups in the functional feeding group of scrapers. We preferred to classify as periphyton feeders the insects having a mixture of algae, organic matter, and microbiota in their digestive tracts, just as Uieda et al. (1997) did in the case of fish. 


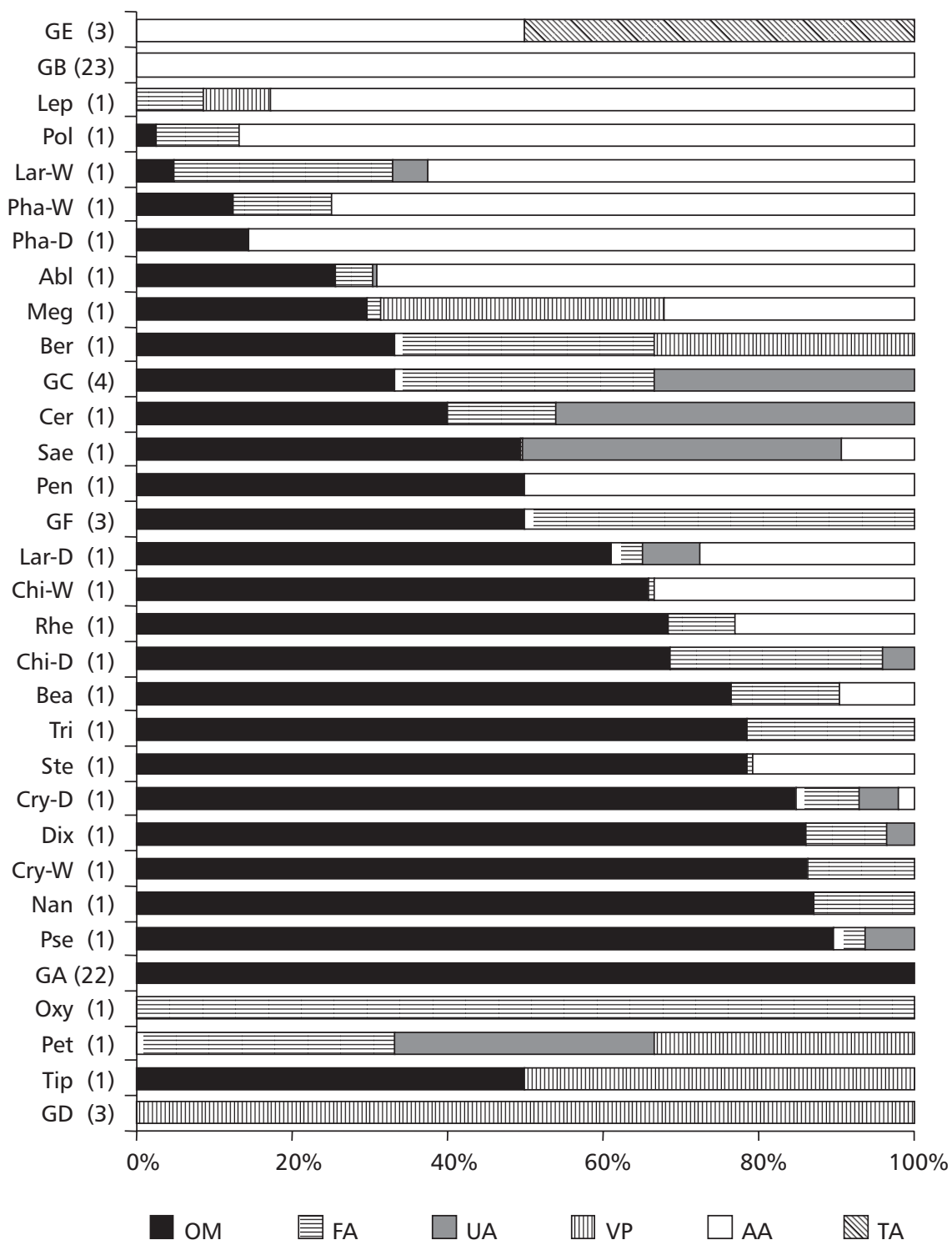

Fig. 1 - Biovolume (\%) of food items in the diet of invertebrate taxa sampled in the Ribeirão do Atalho. The resources categories are: $\mathrm{OM}=$ Organic matter, $\mathrm{FA}=$ Filamentous algae, $\mathrm{UA}=$ Unicellular algae, $\mathrm{VP}=$ Vascular plants, $\mathrm{AA}=\mathrm{Aquatic}$ animals, and $\mathrm{TA}=$ Terrestrial animals. $\mathrm{W}$ (wet) and D (dry) refer to the taxa with seasonal variation in diet. L (larvae) and A (adult) represent taxa with ontogenetic variation in diet; unless otherwise indicated, the insects are larvae. Taxa with similar diets were grouped by the same letter (number of taxa). Group A = Leptophlebiidae, Macronema, Oxyethira (W), Heterelmis (L), Tropisternus (A), Chaetocladius (W), Chelifera (D), Corynoneura, Cricotopus, Djalmabatista, Empididae sp. 1, Eukiefferiella, Forcipomyiinae (W), Hemerodromia, Orthocladius, Polypedilum sp. 1, Psychoda, Rheotanytarsus (D), Tanytarsus, Agabus (D, A), Parametriocnemus, and Ceratopogonidae (W); Group B = Castoraeschna, Corduliidae (W), Dasythemis, Enallagma, Erythrodiplax, Hetaerina, Neocordulia, Phyllogomphoides, Progomphus, Zonophora, Leptonema (D), Marilia, Smicridea, Gyretes (L), Gyrinus (A), Laccophilus (A), Megadytes (L), Nanocladius (D), Belostoma, Pelocoris, Paravelia, Rhagovelia, and Limnocoris; Group C = Neotrichia, Simuliidae, Thienemanniella, and Limnophyes; Group D = Parapoynx, Hydrotassa (A), and Lixus (A); Group E = Graptocorixa, Agabus (W, A), and Gyretes (A); Group F = Gripopterix, Paragripopterix, and Chelifera (W). Taxon abbreviations: Oxy = Oxyethira (D), Pen = Pentaneura, Tip $=$ Tipulidae, Ber $=$ Berosus $(\mathrm{A})$, Pet $=$ Petrophila, Tri $=$ Tribelos, Nan $=$ Nanocladius $(\mathrm{W})$, Cry $-\mathrm{W}=$ Cryptochironomus $(\mathrm{W})$, Chi-D = Chironomus $(\mathrm{D})$, Dix $=$ Dixella, Pse $=$ Pseudochironomini, Cry-D = Cryptochironomus $(\mathrm{D})$, Ste $=$ Stenochironomus, Bea = Beardius, Chi-W = Chironomus $(\mathrm{W})$, Rhe $=$ Rheotanytarsus $(\mathrm{W})$, Lar-D = Larsia $(\mathrm{D})$, Sae $=$ Saetheria, $\mathrm{Cer}=$ Ceratopogonidae $(\mathrm{D}), \mathrm{Meg}=$ Megadytes $(\mathrm{A}), \mathrm{Abl}=$ Ablabesmyia, $\mathrm{Pha}-\mathrm{W}=$ Phanopsectra $(\mathrm{W})$, Pha-D = Phanopsectra (D), Lar-W = Larsia $(\mathrm{W})$, Po = Polypedilum sp. 2, and Lep = Leptonema $(\mathrm{W})$. 


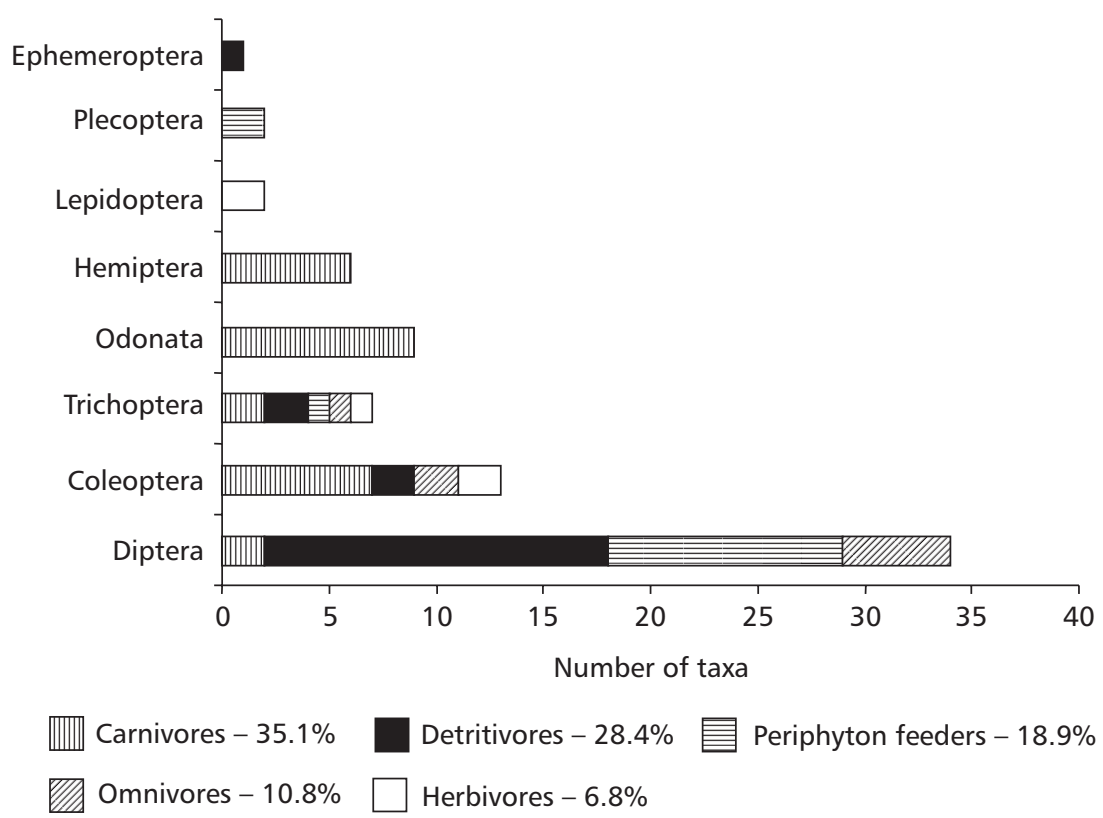

Fig. 2 - Relative composition of the insect orders as to trophic groups (the feeding group taxa richness is expressed in percentages).

In the Ribeirão do Atalho, particulate organic matter was present in the diet of specimens of most aquatic insects. Although dipterans (most chiromid larvae) presented a highly diversified diet including several resources, detritivory was the most important trophic group characteristic of this order. The same pattern was observed by Henriques-Oliveira $e t$ al. (2003) in studying the feeding habits of chiromid larvae in a tropical stream (Rio de Janeiro State, Brazil). Chiromids have an important role in the food webs of streams, representing a major link between primary producers and the top levels (Motta, 1996). Despite the high organic matter exploitation observed among different insect orders, organic matter is a non-limited resource in the stream ecosystem, which is of both allochthonous and autochthonous origin. Thus, partitioning of this food resource among a high number of species is a possibility.

In the Ribeirão do Atalho, periphyton feeders also used organic matter as a food resource. Stoneflies, one example of caddisfly genera, and a high number of dipteran genera were periphyton feeders. Several authors (Otto, 1983; Cummins \& Klug, 1979; Allan, 1995; Winterbourn, 1995) have emphasized the importance of periphyton as a direct food source for many taxa. Mihuc \& Minshall (1995) found that periphyton presents a high nutritional quality, since it was used for growth by 7 of the 11 taxa studied by those authors in North American streams. According to Winterbourn (1995), many stoneflies, caddisflies, mayflies, and beetles that inhabit rivers and streams of New Zealand feed on both algae and organic matter associated with a given microbiota. Froehlich \& Oliveira (1997) found that the South American stoneflies (Grypopterygidae) consumed algae and organic matter.

Two autotrophic food sources were important for some insect groups of Ribeirão do Atalho: aquatic macrophytes and algae. Herbivorous lepidopterans (Pyralidae) and beetles (Crysomelidae and Curculionidae) consumed aquatic macrophytes. According to some authors (Cummins \& Klug, 1979; Harper, 1986; Allan, 1995) macrophytes, because of their low digestibility and high levels of cellulose and lignin, are rarely attacked by aquatic herbivores in running water. Jacobsen (1993) reported that about $95 \%$ of aquatic macrophyte exploitation is due to larval lepidopterans (mainly Pyralidae); 18\%, to aquatic beetles (mainly Curculionidae and Chrysomelidae); and 5\%, to larval dipterans (mainly Chironomidae). 


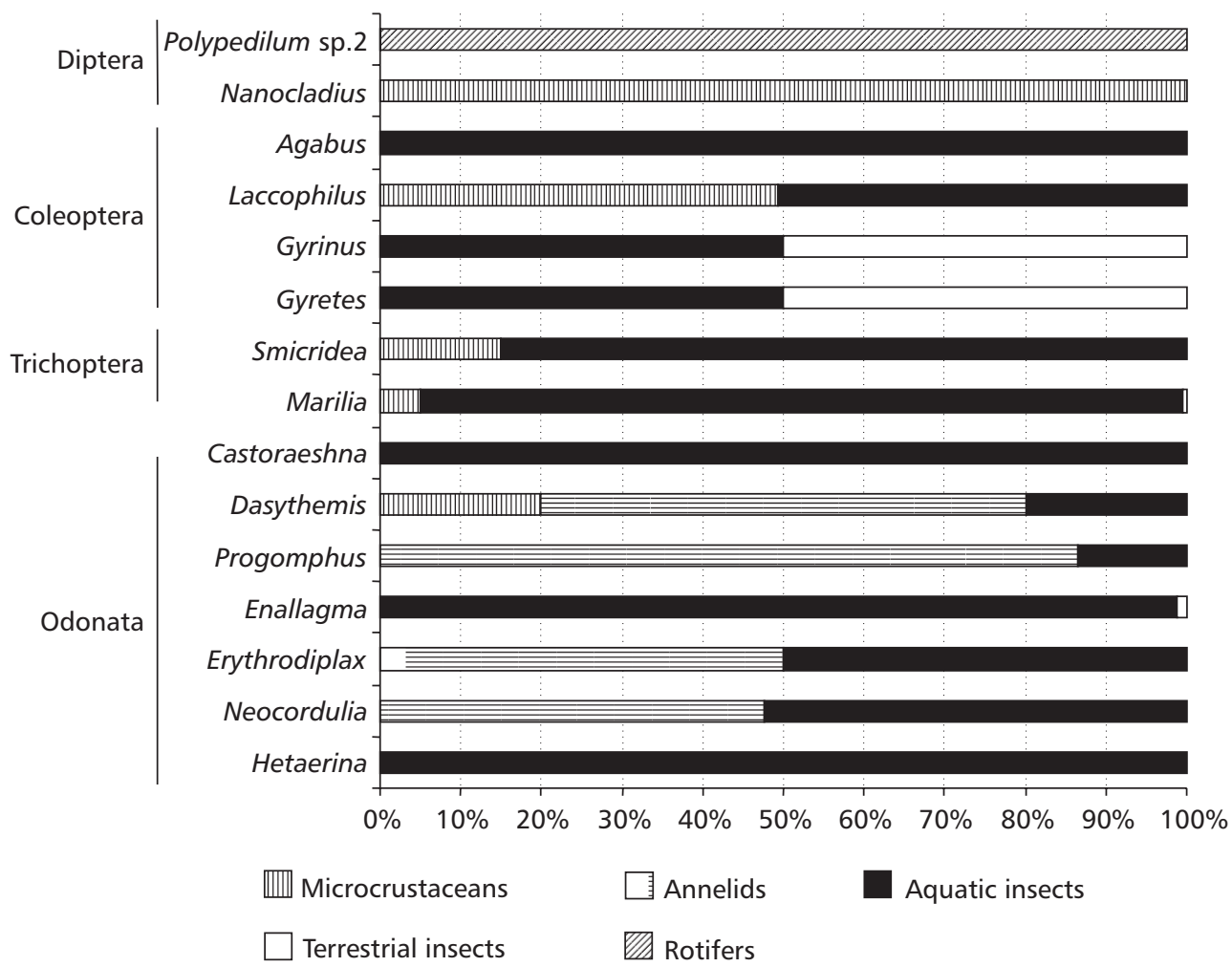

Fig. 3 - Spectrum of prey items (\% biovolume) in the diet of carnivorous aquatic insects sampled in the Ribeirão do Atalho.

TABLE 1

Trophic structure (percentage of taxa by trophic group) of the insects sampled in the Ribeirão do Atalho during the wet and dry seasons.

\begin{tabular}{|l|c|c|}
\hline \multicolumn{1}{|c|}{ Trophic groups } & Wet & Dry \\
\hline Carnivores & 36.7 & 40.4 \\
\hline Detritivores & 28.3 & 24.6 \\
\hline Periphyton feeders & 20.0 & 19.3 \\
\hline Omnivores & 8.3 & 10.5 \\
\hline Herbivores & 6.7 & 5.3 \\
\hline
\end{tabular}


WET

Trichoptera

TA

\begin{tabular}{|l|l|}
\hline$C$ & 2 \\
\hline$D$ & 2 \\
\hline$P F$ & 1 \\
\hline$O$ & 1 \\
\hline$H$ & - \\
\hline
\end{tabular}

AA

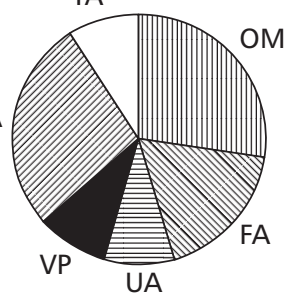

Lepidoptera
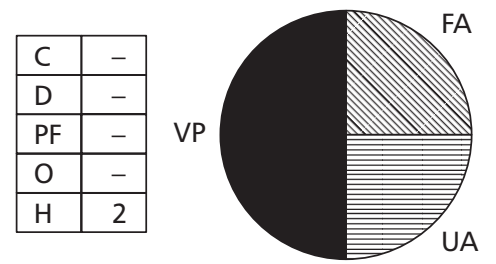

Coleoptera

\begin{tabular}{|l|r|}
\hline$C$ & 7 \\
\hline$D$ & 2 \\
\hline$P F$ & - \\
\hline$O$ & 1 \\
\hline$H$ & 2 \\
\hline
\end{tabular}

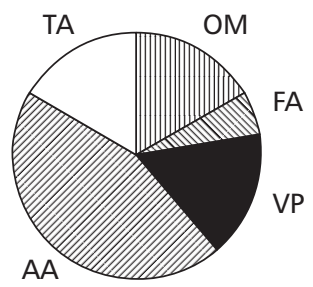

Diptera

\begin{tabular}{|l|c|}
\hline C & 1 \\
\hline D & 12 \\
\hline PF & 9 \\
\hline O & 3 \\
\hline H & - \\
\hline
\end{tabular}

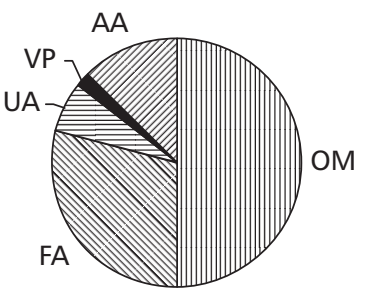

DRY

Trichoptera

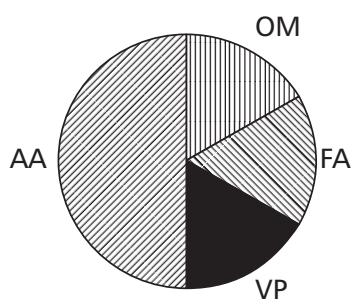

\begin{tabular}{|c|c|}
\hline C & 3 \\
\hline D & - \\
\hline PF & - \\
\hline O & - \\
\hline$H$ & 1 \\
\hline
\end{tabular}

Lepidoptera

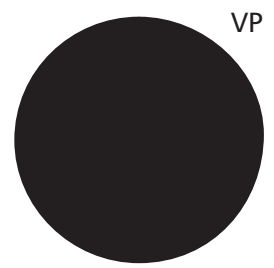

\begin{tabular}{|c|c|}
\hline C & - \\
\hline D & - \\
\hline PF & - \\
\hline O & - \\
\hline$H$ & 1 \\
\hline
\end{tabular}

Coleoptera

TA

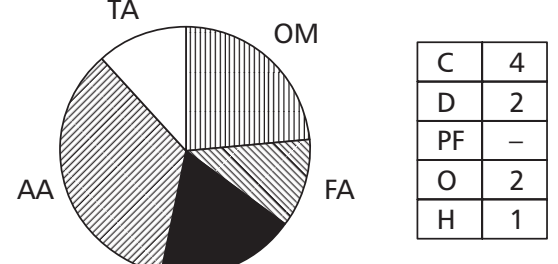

Diptera

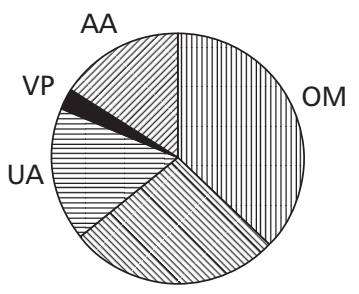

\begin{tabular}{|c|c|}
\hline C & 2 \\
\hline D & 11 \\
\hline PF & 9 \\
\hline O & 4 \\
\hline$H$ & - \\
\hline
\end{tabular}

Fig. 4 - Gut content of the aquatic insects of four orders, with seasonal variations, sampled in the Ribeirão do Atalho during the wet (December) and dry (August) seasons, and the functional feeding group composition (table with the taxa richness per trophic group). $\mathrm{OM}=$ organic matter, $\mathrm{FA}=$ filamentous algae, $\mathrm{UA}=$ unicellular algae, $\mathrm{VP}=$ vascular plants, $\mathrm{AA}=$ aquatic animals, $\mathrm{TA}=$ terrestrial animals, $\mathrm{C}=$ carnivores, $\mathrm{D}=$ detritivores, $\mathrm{PF}=$ periphyton feeders, $\mathrm{O}=$ omnivores, and $\mathrm{H}=$ herbivores. 
Algae, also an important autotrophic food item, was included in the diet of insects of different trophic groups, e.g., herbivores, periphyton feeders, and omnivores. However, a diet based exclusively on algae was observed only for a caddisfly (Oxyethira) in the dry season. Winterbourn (1995) also reported filamentous algae consumption by Oxyethira in small New Zealand streams. It is possible that the diet of this genus is defined more by community resource partitioning than by a feeding preference. In Ribeirão do Atalho, Motta (1996) found more filamentous algae during the wet season, when Oxyethira preferred detritus.

Animal items, considered the highest-quality source of calories and protein as well as having high diversity in streams, are used by several insect orders (Cummins \& Klug, 1979). Carnivorous genera showed the greatest feeding overlap within some orders rather than between orders. Among carnivorous insects the greatest richness of genera was observed in the Odonata order. Although the diet was similar between different genera (based mainly on aquatic insects and annelids), these Odonata consumed different insect orders, reducing the feeding overlap degree between the genera. In addition, Dudgeon (1995) reported that Odonata genera are specialized predators and consume prey of different kinds and size classes.

The great diversity of food habits presented by caddisflies, beetles, and dipterans was evidenced by the fact that these were the only orders to present omnivorous genera in our study. In addition, Trichoptera was the only order to present genera of all trophic groups in the Ribeirão do Atalho. According to Wiggins \& Mackay (1978), omnivory is common in Trichoptera larvae and a substantial number of this genera have varied feeding habits. Merritt \& Cummins (1996) showed that the dietary habits of caddisflies, beetles, and dipterans vary thoroughly, thus any generalization regarding their diet is difficult. The diversity of mechanisms used to capture food by these orders allows the exploitation of several food sources (Merritt \& Cummins, 1996), consequently increasing taxon richness.

\section{Seasonal variation}

According to Cummins \& Klug (1979), seasonal and local differences in input, production, and reserves of food resources upon which aquatic insects feed provide a dynamic system with variability in space and time. Although the functional group categories are based partially on species morphology, there is considerable flexibility in the mode of feeding, as emphasized by Henriques-Oliveira et al. (2003) for chironomids, and Merritt \& Cummins (1996) for all aquatic insects. Such flexibility probably facilitates adaptation of aquatic insects to seasonal changes in food availability in a given environment. In our study, this flexibility was notable when carnivore genera changed into a detritivorous, omnivorous, or periphyton feeder. Seasonal changes also occurred when genera changed from the periphyton feeder group into the detritivorous or omnivorous, but these are not extreme changes since insects of all three feeding groups ingest, although in different proportions, similar food items.

The seasonal trophic structure similarity at the community level observed in the Ribeirão do Atalho stream might indicate constant food resource availability, an aseasonal trophic feature. This possibility was reinforced by the results on the Coleoptera and Diptera orders, which showed a seasonal trophic group change involving only a modification in the proportion of food items ingested during the dry and wet seasons. A minor importance of seasonal changes in functional feeding groups was also reported by Lake (1995) in a perennial inland stream in Southeastern Australia, and by Yule (1996) in Konaino Creek (Papua New Guinea).

In conclusion, trophic structure stability of the insect community studied in the Ribeirão do Atalho may be related to the great importance of organic matter as a food resource for this community. Thus, organic matter may be an important non-limited food resource with influence upon the insect communities of tropical and subtropical streams (this study; Closs \& Lake, 1994; Havens et al., 1996; Motta, 1996).

Acknowledgements - We are grateful to Hamilton Antônio Rodrigues for field assistance and to CNPq for grants to the first author. This study was supported by FAPESP (Proc. 90/ 2410-8, Proc. 91/0612-5)

\section{REFERENCES}

ALLAN, J. D., 1995, Stream Ecology. Chapman \& Hall, London, $388 \mathrm{p}$.

BAY, E. C., 1974, Predator-prey relationships among aquatic insects. Annu. Rev. Ent., 18: 441-453.

CLOSS, G. P. \& LAKE, P. S., 1994, Spatial and temporal variation in the structure of an intermittent-stream food web. Ecol. Monographs, 64: 1-21.

CUMMINS, K. W., 1973, Trophic relations of aquatic insects. Апnи. Rev. Ent., 18: 183-206. 
CUMMINS, K. W. \& KLUG, M. J., 1979, Feeding ecology of stream invertebrates. Annu Rev. Ecol. Syst., 10: 147-172.

DUDGEON, D., 1995, The ecology of rivers and streams in tropical Asia. In: C. E. Cushing, K. W. Cummins \& G. W. Minshall (eds.), River and stream ecosystems. Elsevier Science, Amsterdam, 817p.

ESTEVES, K. E. \& GALETTI-JUNIOR, P. M., 1995, Food partitioning among some characids of a small Brazilian floodplain lake from the Paraná River basin. Environ. Biol. Fishes, 42: 375-389.

FROEHLICH, C. G. \& OLIVEIRA, L. G., 1997, Ephemeroptera and Plecoptera nymphs from riffles in low-order streams in southeastern Brazil, pp.180-185. In: P. Landolt \& M. Sartori (eds.), Ephemeroptera \& Trichoptera: BiologyEcology-Systematics. MTL, Fribourg.

HARPER, P. P., 1986, Relations entre les macrophytes et les insectes dans les milieux d'eau douce. Rev. D'Ent. du Quebec, 31: 76-86.

HAVENS, K. E., BULL, L. A., WARREN, G. L., CRISMAN, T. L., PHILIPS, E. J. \& SMITH, J. P., 1996, Food web structure in a subtropical lake ecosystem. Oikos, 75: 2029.

HENDERSON, P. A. \& WALKER, I., 1986, On the leaf litter community of the Amazonian backwater stream Tarumãzinho. J. Trop. Ecol., 2: 1-17.

HENRIQUES-OLIVEIRA, A. L., NESSIMIAN, J. L. \& DORVILLÉ, L. F. M., 2003, Feeding habits of Chironomid Larvae (Insecta: Díptera) from a stream in the Floresta da Tijuca, Rio de Janeiro, Brazil. Braz. J. Biol., 63: 269-281.

HYNES, H. B. N., 1970, The ecology of running waters. Toronto Press, Canada, 555p.

JACOBSEN, D., 1993, Trichopteran larvae as consumers of submerged angiosperms in running waters. Oikos, 67: 379383.

KING, J. M., DAY, J. Á., HURLEY, P. R., HENSHALLHOWARD, M. P. \& DAVIES, B. R., 1988, Macroinvertebrate communities and environment in a southern African mountain stream. Can. J. Fish. Aquat Sci., 45: 2168-2181.

LAMBERTI, G. A. \& MOORE, J. W., 1984, Aquatic insects as primary consumers. In: V. H. Resh \& D. M. Rosemberg (eds.), The ecology of aquatic insects. Blackwell, New York, $625 \mathrm{p}$.

LAKE, P. S., 1995, Of floods and droughts: river and stream ecosystems of Australia. In: C. E. Cushing, K. W. Cummins \& G. W. Minshall (eds.), River and stream ecosystems. Elsevier Science, Amsterdam, 817p.

MERRITT, R. W. \& CUMMINS, K. W., 1996, An introduction to the aquatic insects of North America. Kendall/Hunt, Dubuque, 862p.
MIHUC, T. B. \& MINSHALL, G. W., 1995, Generalists vs. trophic specialists: implications for food web dynamics in post-fire streams. Ecology, 76: 2361-2372.

MOTTA, R. L., 1996, Trama alimentar das comunidades animais em um curso de água corrente (Ribeirão do Atalho, Itatinga $S P)$. Instituto de Biociências, UNESP, Botucatu, SP, 154p.

NESSIMIAN, J. L., 1997, Categorização funcional de macroinvertebrados de um brejo de dunas no Estado do Rio de Janeiro. Rev. Brasil. Biol., 57: 135-145.

NESSIMIAN, J. L. \& SANSEVERINO, A. M., 1998, Trophic functional categorization of the chironomid larvae (Diptera: Chironomidae) in first-order stream at the mountain region of Rio de Janeiro State, Brazil. Verh. Internat. Verein. Limnol., 26: 2115-2119.

NESSIMIAN, J. L., SANSEVERINO, A. M. \& OLIVEIRA, A., 1999, Relações tróficas de larvas de Chironomidae (Díptera) e sua importância na rede alimentar em um brejo de dunas no Estado do Rio de Janeiro. Revta. Brasil. Entomol., 43: 47-53.

OTTO, C., 1983, Adaptations to benthic freshwater herbivory. In: R. G. Wetzel (ed.), Periphyton of freshwater ecosystems. Dr. W. Junk, Boston, 346p.

UIEDA, V. S., BUZZATO, P. \& KIKUCHI, R. M., 1997, Partilha de recursos alimentares em peixes em um riacho de Serra do Sudeste do Brasil. An. Acad. Brasil. Ciênc., 69: 243252.

WAIS, I. R., 1990, A checklist of the benthic macroinvertebrates of the Negro River Basin, Patagonia, Argentina, including an approach to their functional feeding groups. Acta Limnol. Brasiliensia, 2: 829-845.

WALLACE, J. B., BENKE, A. C., LINGLE, A. H. \& PARSONS, K., 1987, Trophic pathways of macroinvertebrate primary consumers in subtropical blackwater streams. Arch. Hydrobiol., 74: 423-451.

WIGGINS, G. B. \& MACKAY, R. J., 1978, Some relationships between systematics and trophic ecology in Neartic aquatic insects, with special reference to Trichoptera. Ecology, 59: $1211-1220$

WINTERBOURN, M. J., 1995, River and stream of New Zealand. In: C. E. Cushing, K. W. Cummins \& G. W. Minshall (eds.), River and stream ecosystems. Elsevier Science, Amsterdam, 817p.

WINTERBOURN, M. J., COWIE, B. \& ROUNICK, J. S., 1994, Food resources and ingestion patterns along a West Coast, South Island, river system. $N$. Z. J. Marine Freshwater Res., 18: $379-388$.

YULE, C. M., 1996, Trophic relationship and food webs of the benthic invertebrate fauna of two seasonal tropical streams on Bougainville Island, Papua New Guinea. J. Trop. Ecol., 12: $517-534$ 